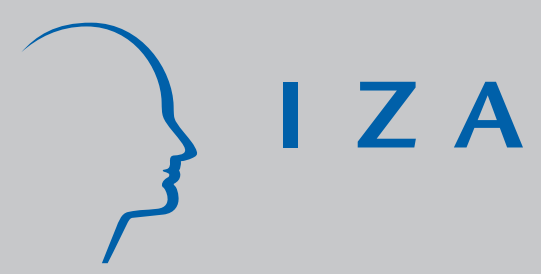

IZA DP No. 189

Is Unemployment Really Scarring? Effects of Unemployment Experiences on Wages

Wiji Arulampalam

August 2000 


\title{
Is Unemployment Really Scarring? Effects of Unemployment Experiences on Wages
}

\author{
Wiji Arulampalam \\ Department of Economics, University of Warwick and IZA, Bonn
}

Discussion Paper No. 189

August 2000

\author{
IZA \\ P.O. Box 7240 \\ D-53072 Bonn \\ Germany \\ Tel.: +49-228-3894-0 \\ Fax: +49-228-3894-210 \\ Email: iza@iza.org
}

This Discussion Paper is issued within the framework of IZA's research area The Welfare State and Labor Markets. Any opinions expressed here are those of the author(s) and not those of the institute. Research disseminated by IZA may include views on policy, but the institute itself takes no institutional policy positions.

The Institute for the Study of Labor (IZA) in Bonn is a local and virtual international research center and a place of communication between science, politics and business. IZA is an independent, nonprofit limited liability company (Gesellschaft mit beschränkter Haftung) supported by the Deutsche Post AG. The center is associated with the University of Bonn and offers a stimulating research environment through its research networks, research support, and visitors and doctoral programs. IZA engages in (i) original and internationally competitive research in all fields of labor economics, (ii) development of policy concepts, and (iii) dissemination of research results and concepts to the interested public. The current research program deals with (1) mobility and flexibility of labor markets, (2) internationalization of labor markets and European integration, (3) the welfare state and labor markets, (4) labor markets in transition, (5) the future of work, (6) project evaluation and (7) general labor economics.

IZA Discussion Papers often represent preliminary work and are circulated to encourage discussion. Citation of such a paper should account for its provisional character. 
IZA Discussion Paper No. 189

August 2000

\section{ABSTRACT \\ Is Unemployment Really Scarring? Effects of Unemployment Experiences on Wages*}

This paper looks at the effects of unemployment on re-employment wage for men using the first seven waves of the British Household Panel Survey (BHPS) conducted over the period 19911997. In particular, how the effect of an interruption changes over time, and whether the type of interruption itself matters or not for re-employment wage, are addressed. The issue of sample selection and unobserved heterogeneity are also addressed in the analyses. This study finds that, unemployment does have a scarring effect on individuals who experience it, in terms of earnings losses on re-employment jobs. In particular it finds that, an unemployed individual on returning to work will earn about $6 \%$ less than an otherwise equivalent individual who makes an employment to employment transition, during the first year of employment. This differential is estimated to increase to about $14 \%$ in the fourth year before starting to decline. In addition, the first spell of unemployment is estimated to have the largest effect with repeat incidences causing a further scarring. Separations due to redundancy are found to be less scarring relative to other causes. The worst affected were men aged over 45 with no educational qualifications. The study could not find any significant effects of unemployment duration on subsequent wages in addition to the incidence effect.

JEL Classification: J30, J60

Keywords: Wage losses, unemployment effects, scarring, re-entry wages

Wiji Arulampalam

Department of Economics

University of Warwick

Coventry CV4 7AL

Tel: $+44(0) 2476523471$

Fax: +44 (0)247652 3032

Email: wiji.arulampalam@warwick.ac.uk

\footnotetext{
* The BHPS data used in this paper were collected by the ESRC Research Centre on Micro-Social Change at the University of Essex, and made available through the ESRC Data Archive. I should like to thank Mark Taylor for providing help with the creation of some of the variables used in the study and to the Institute for Social and Economic Research Centre for providing the data on Travel-To-Work-Area unemployment and vacancy rates. Any errors remain my responsibility. I am grateful to Alison Booth, Paul Gregg, Robin Naylor, Mark Stewart, Mark Taylor, Jonathan Wadsworth, lan Walker, Myrna Wooders, and seminar participants at the Employment and Education Economics Group Meeting held in May 2000, Centre for Economic Performance, London School of Economics, and University of Warwick. This paper was produced as part of the project on Unemployment and Technical and Structural Change, which was funded by the Leverhulme Trust. The views in the paper are those of the author, and do not necessarily reflect those of the Leverhulme Trust
} 


\section{INTRODUCTION}

It is generally found that, an experience of unemployment increases the chances of a future unemployment experience. ${ }^{1}$ A policy intervention is required if these individuals, as well as experiencing loss of income during the periods of unemployment, are also further 'scarred' by their unemployment experiences, in the sense of being paid less than an otherwise equivalent individual who has not experienced an unemployment spell. ${ }^{2}$ The scarring effect will not only contribute to wage inequality and poverty, but can also interfere with work incentives. This paper investigates this issue of scarring. In particular, this paper seeks an answer to the question on whether individuals who enter a job via a spell of unemployment experience only an initial temporary loss in earnings relative to individuals who make a job-to-job transition, or whether the loss is permanent. ${ }^{3}$

If there was a penalty attached to an unemployment experience, this could be due to several reasons. First, employers might use an individual's unemployment history in order to sort good workers from bad workers (Lockwood (1991)) and this might result in loss of wage if the employer, at least initially, decides to pay the individual less than his/her marginal product. This will happen if employers perceive, rightly or wrongly, that individuals lose acquired human capital during a spell out of employment (Pissarides (1992)). Second, an unemployed individual for various reasons (loss of unemployment benefits, liquidity constraints, disutility from leisure etc.) might revise his/her reservation wage downwards as the spell lengthens, and incur a wage loss.

$1 \quad$ For Britain, see Narendranathan and Elias (1993), Arulampalam et al (2000).

2 Gregg and Wadsworth (1996) argue that labour supply shocks and cost shocks have been responsible for increases in the so-called 'low-quality' jobs in the 1990s relative to the 1970s, and that these jobs are being taken up by individuals who are non-employed. Stewart (2000) argues that a reason for observed persistence in the unemployment status is due to individuals who experience unemployment going into jobs that are low paid and unstable. Boheim and Taylor (2000) find that jobs that follow an unemployment spell have shorter mean duration than other jobs.

3 This is very different to other recent studies related to the United Kingdom. For example, in Gregory and Jukes (1999) and in Nickell et al (1999), the post interruption wages do not necessarily refer to wages in the immediately proceeding spell of employment. 
It is also possible that post-unemployment wage might be higher than the preunemployment wage if for example the individual voluntarily changes jobs with an intervening spell of unemployment in order to improve his/her earnings. An unemployment spell also might help an individual to search better for a better-matched job giving a wage gain.

Two important related issues need to be addressed in any analysis that compares wages. One is to do with what, or who is the comparison group. The second is to do with the points at which the wage information is measured. Existing extensive literature on the effect of displacement on subsequent earnings has mainly emphasised on the comparison between pre and post separation wages via a wages growth equation. ${ }^{4,5}$ It is generally found that wages of workers who had separated (usually defined as due to plant closure or mass layoffs) from long tenure jobs, had already started to fall well before the occurrence of the actual separation. In addition, when separated individuals are re-employed, the recovery of the wages relative to preseparation wages is found to take a very long time. ${ }^{6}$ The length of separation, and also the time in employment up to the point of the wage measurement, are thus important as both will affect the measurement of the wage loss associated with the separation. Hence, unless one has longitudinal information on pre and post separation wages, comparison of just one pre-separation wage with one post-separation wage may under estimate the loss associated with the separation.

If individuals experience repeat spells of unemployment, for policy purposes, it is more important to compare these individuals with those who do not experience unemployment. ${ }^{7}$ In this study, comparisons are therefore carried out on two otherwise equivalent individuals except

$4 \quad$ For a survey of the effects of worker displacement, see Fallick (1996) and Kletzer (1998).

5 Wages growth equation is also sometimes used because of lack of longitudinal information. If one only has one pre and one post separation wage information, to account for unobservables in the equation, the dependent variable is measured as the difference in the two wages which will be the approximate wages growth if wages are in logs.

6 Using administrative data on a group of workers in Pennsylvania, Jacobson et al (1993) found that, for high tenure prime age men who were part of mass-layoffs in 1982, quarterly earnings had started to decline substantially three years prior to their separation and recovery was very slow with losses still around $25 \%$ of their pre-displacement earnings even after five years from separation. In contrast, using administrative data on registered unemployment and earnings of British men for the years 1984-94, Gregory and Jukes (1997) found unemployment incidence to have only a $10 \%$ temporary effect on hourly earnings that disappeared over two years on re-engagement. But unlike this study, the job considered is not the immediate job after the unemployment. 
one has moved into current employment via a spell of unemployment and the other had not. Since both individuals would have the same current employment tenure, any time effect of the unemployment spell will coincide with the returns to tenure in the current employment. This is very different to what is usually carried out in this type of analysis.

This study uses a sample of men drawn from the British Household Panel Survey data (BHPS) over the period 1991 to 1997 to address the issue of the effect of an interruption on the subsequent wages. Unlike most of the data set that had been used in the literature, the BHPS has retrospective information on labour market history. This has a very big advantage since the analysis need not be confined to interruptions that took place during the sample observation period. $^{8}$ One is able to trace back and date the last separation and also other separations using the retrospective information. Hence the effects of multiple spells of unemployment and also the duration of the spell on subsequent wages can be addressed. In addition, more importantly, information on the cause of job loss or change is available. This enables one to look at the effects of voluntary versus involuntary separation. The panel nature of the data set also allows one to address the issues of unobservable individual characteristics and sample selection.

In summary, this study while looking at the effects of an interruption on re-entry wages also addresses the following. (i) Does the wage effect of the interruption vary with the type of interruption? (ii) Are the effects of an interruption temporary and if so how long do they last for? (iii) Do multiple spells of interruptions have additional wage losses associated with them? (iv) Is it only the incidence of interruption that matters or does the actual duration of the interruption also has an impact on post-interruption earnings?

Using data from the Panel Study of Income Dynamics for 1968-88, Stevens (1997) finds that much of the estimated persistence in wage/earnings losses can be explained by additional job losses following an initial displacement.

8 Although Borland et al (1998) used the BHPS data set for their analysis, they restricted their unemployment spell to those that occurred during the observation period 1991-1996 and looked at the effect of an interruption on wage growth between pre and post interruption wages. Nickell et al (1999) also imposed the same restriction. On the other hand, Gregory and Jukes imposed the restriction that the effects of registered unemployment only has a time dependent effect up to about 2 years in order to minimise on the loss of data because of lack of retrospective information. 
In Section 2 of the paper, the econometric model chosen to deal with these problems is elaborated. The data and the sample used for the analysis are described in Section 3. Section 4 presents and discusses the basic model estimates and some model extensions are considered in Section 5. The final section summarises and concludes.

\section{THE MODEL SPECIFICATION AND ESTIMATION}

There are two important related econometric issues that need to be dealt with in this type of analysis. The first is to do with unobserved heterogeneity. In the standard human capital model, returns to tenure and experience are interpreted as returns to specific and general human capital respectively. In these models, high tenure workers are better paid because their productivity rises with time on the job and more experience implies more acquired general skills. But, search models have been put forward as an alternative. Here the explanation given for the returns to tenure and experience is in terms of selectivity and matching arguments. The selectivity argument is that, more able workers will face better promotion prospects and thus will have high tenure. The matching argument is that a match between a firm and an individual will last longer if it is a 'good' match and also more experienced workers would have had more time to find a good match. Tenure and experience variables are thus functions of past quits and lay-off decisions. As a result, tenure and experience variables will be correlated with unobservable job specific or match specific variables. Hence, ordinary least squares (OLS) estimation of a standard earnings function using cross-sectional data will produce biased estimates of the returns to tenure and experience. ${ }^{9}$ It is therefore important to account for unobservable individual heterogeneity and unobservable job-match heterogeneity in the estimation. Although the longitudinal nature of this data set enables one to control for unobservables, one is unable to distinguish the cause of positive returns to tenure. Information on firm and job characteristics is

9 Some examples of studies that have tried to address the issue of endogeneity of tenure are, Abraham and Farber (1987), Altonji and Shakotko (1987), Topel (1991), Altonji and Williams (1997), and Dustmann and Meghir (1998). 
used to control for this. ${ }^{10}$ Thus, all correlations are assumed to be adequately captured by the use of extensive individual, firm, and employer characteristics, as well as allowance for unobservable time-invariant individual specific characteristics.

In order to deal with various issues discussed, one requires at least two wage observations. This takes us to the second econometric issue that is the possibility of sample selection bias that is addressed in this paper.

Consider the following log-linear wage equation:

$$
\mathrm{w}_{i t} \equiv \ln \left(\mathrm{W}_{i t}\right)=\mathbf{x}_{i t} \boldsymbol{\beta}^{\boldsymbol{\beta}}+\left(d_{i t}^{*} \mathbf{z}_{i t}\right)^{\prime} \boldsymbol{\gamma}+\alpha_{i}+\mathrm{u}_{i t}, \quad i=1, \ldots n \quad \text { and } t=1, \ldots, T_{i}
$$

where $\mathrm{w}_{\mathrm{it}}$ is the natural logarithm of wage at time $\mathrm{t}$ for individual $\mathrm{i}$; $\mathbf{x}_{\mathbf{i t}}$ is a vector of observable variables on both individual as well as firm characteristics which can be time varying or invariant; $d_{i t}$ is a dummy variable which takes the value of one if the individual had come into this employment via a spell of interruption; $\mathbf{z}_{i t}$ is a vector of observable variables on individual characteristics; $\alpha_{i}$ is a time-invariant individual specific error term capturing the effects of unobservable characteristics; $\mathrm{u}_{i t}$ is the equation error term.

The possible correlation between the unobservables and the observables need to be accounted for in the estimation of the parameters of interest, $\boldsymbol{\beta}$ and $\boldsymbol{\gamma}$. Hence the above model is estimated using within-group (WG) estimation, which is a simple least squares estimation of the model in which the variables are defined as deviations from their individual means. ${ }^{11}$

The correction for possible sample selection bias is carried out by an addition of the standard Heckman correction term in the wage equation. This essentially is a cross-section

10 If there are omitted individual-job specific unobservables in the equation, correlation between these and the tenure variables can either result in an upward biased estimate (Altonji and Shakotko (1987)), or in a downward biased estimate of the returns to tenure (Topel (1991)). A good match implies a lower turnover since the individual will be less likely to quit and hence a positive correlation between tenure and job-match variable. On the other hand, individuals who have high turnover are the individuals who move to obtain a better job match and hence turnover will be negatively correlated with tenure. This is a very difficult issue to resolve unless one is prepared to make some assumptions regarding the nature of correlation and also have access to a very rich data set with information on individual's full labour market history along with the associated wages.

11 Taking first differences to eliminate the unobservables is another technique that can be used. Since the wage observations do not necessarily refer to two consecutive years, this study uses within-group estimation. 
analysis. Any biases that are time-invariant due to sample selection are already accounted for in the WG estimation. In order to allow for possible time-varying biases, the selection term was interacted with time dummies in the models estimated. ${ }^{12}$

\section{THE DATA}

The data used for the analyses are from the first seven waves of the British Household Panel Survey (BHPS), which is a nationally representative survey of around 5,500 households randomly selected South of the Caledonian Canal. The first wave of the BHPS was conducted in the autumn of 1991, and annually thereafter (for details, see Taylor (1996)). Information on labour market status is recorded at each interview, and for the period beginning on 1 September a year prior to the interview. In addition to the normal set of questions, at the second wave of interviews (in 1992), respondents were asked to detail their complete labour market histories since leaving full-time education for the first time. In 1993, at the third wave, complete job history data were also collected. The analysis presented in this paper uses information from regular questions as well as the two additional retrospective lifetime data.

At each interview, the respondent is asked about the current labour market status. If the individual is currently employed, details about the current job are collected. If the individual started this particular job after the 1 September of the previous year, only then is the information about the previous labour market status collected. As an example, consider an individual who was present in waves 1 and 3 but not in wave 2. Supposing this individual started a job sometime between wave 1 interview date and $1^{\text {st }}$ September 1992 then there is no information about what $\mathrm{s} / \mathrm{he}$ did in the year prior to the job s/he was doing at the time of the third wave

12 The reduced form probit equation for sample selection was estimated as one cross-section in order to account for the fact that there was an overall selection of at least two wage observations per individual over the sample period. This is not just an employment selection alone and hence multinomial probit or logit model is not used for this purpose. 
interview. Hence the analyses on wages presented in this paper has to be restricted to those individuals who were interviewed in consecutive waves starting with the initial wave in $1991 .^{13}$

Selecting men who were aged between 16 and 55 in 1991 and who were directly interviewed by an interviewer in 1991 gave a sample of 3352 men. ${ }^{14}$ The top panel of Table 1 tabulates the total number of direct interviews against the number of employment observations at the time of the interview. In order to avoid problems associated with the measurement of selfemployment hourly earnings, current employment status is defined to exclude self-employment. It is seen from Table 1 that only about $67 \%$ of men have two or more employment observations. Since the analysis is restricted to men who were continuously present in the Survey, the bottom panel of Table 1 presents the same figures for the restricted sample of men. Here, the number of employment observations counted is only over the waves the individual was continuously present.

Of the 3352 men, $85.3 \%(3352-494=2858$ men) were continuously present for at least two years from 1991 (the first wave). The wage equations are estimated for the sub-sample of these men (2031) who said that they were in employment in at least two of the interviews.

The BHPS does have some shortcomings with respect to the analysis of the effects of interruptions. One disadvantage is the fact that very few interruptions are observed in the sample. But the longitudinal nature of BHPS along with very rich information on individual, employer and job characteristics as well as retrospective job history information allows one to control for unobservable individual and job specific effects. Although one is able to increase the number of interruptions by the use of retrospective information, the possibility of bias due to recall errors should be borne in mind in interpreting the results that follow. ${ }^{15}$

13 Analysis of wages of women is more complicated because of interruptions related to family formation and therefore omitted from this work.

14 Analysis had to be restricted to direct personal interview information as many of the variables of interest had missing values in the case of telephone and proxy interviews.

15 Paull (1997) notes that there is a tendency for individuals to redefine time in unemployment as time out of the labour force in the BHPS data set. 


\section{RESULTS}

\subsection{Selection Equation}

This involves the estimation of a reduced form probit using the variable 'employment in at least two waves' on the full sample. Pre-sample information and the 1991 recorded characteristics were used in the estimation of this selection equation. The dependent variable is a dummy that takes the value of 1 if an individual was found to be in employment in at least two waves when he was continuously present from the beginning of the survey (1991) for at least two waves. The dependent variable is set to 0 if the above is not satisfied. Men who were only interviewed in 1991 and never after, men who were not present continuously in the survey, and men who were not in employment in at least two waves, were all coded as having a value of 0 . The selection analysis is based on 3347 men. ${ }^{16}$ The results from this probit equation are presented in Appendix Table A.1. The generalised residuals generated from this probit equation (Heckman's correction for sample selectivity) interacted with time dummies is included in the wage equations that are estimated.

\subsection{Wage equations}

The dependent variable in the wage equation is the real hourly wage that was calculated by dividing the usual weekly gross pay by the usual weekly hours. ${ }^{17}$ Unfortunately, the usual pay includes usual paid overtime as information excluding overtime payment is not available. ${ }^{18}$

The main issue addressed in the paper is the effect of an interruption on re-entry wages. In order to carry this out, previous labour market states considered are employment, unemployment and out-of-the labour force (OLF) (or economic inactivity). Unlike the current labour market status of employment that excludes self-employment, the previous labour market

16 This figure is 5 less than the original figure of 3352 because of deletion of cases with missing values for variables used in the selection equation.

17 If 'hours worked' is measured with errors, using hourly earnings can suffer from measurement errors. But the use of weekly wages will not allow one to control for the fact that some individuals also might be 'scarred' in terms of going back to jobs with fewer hours.

18 Results presented are not sensitive to the assumption that over-time is paid at the rate of 1.5 times the usual hourly rate. 
status of employment includes self-employment. ${ }^{19}$ Individuals in the sample categorise themselves. The retrospective information in the data set does not allow one to distinguish between those who were searching and those who were not searching during these spells. The OLF category includes individuals who had been, long-term sick, at home looking after family, in education or training, etc.

The tenure variable used is the current employer tenure as recorded at the interview. This variable has been grouped into dummy variables instead of using the standard quadratic specification. This was carried out to minimise the effects of measurement error due to problems of recall and also to pick up any higher order non-linearities in the effects of tenure on current wages. The distribution of tenure by previous labour market status is given in Table 2 . Since this study looks at the effect of an interruption on immediately proceeding spell of employment, the employer tenure is the same as the time since interruption for people who had an interruption. Looking at it from the perspective of current employment, $90 \%$ of current employment refers to an employment-to-employment transition. Only about $8 \%$ of current employment refers to unemployment-to-employment transition and about $2 \%$ to an OLF-to-employment transition. Although the time period covered by the actual survey was seven years, it is very interesting to note that only about $20 \%$ of those who had come into this employment spell after a spell of unemployment have recorded current employer tenure to be in excess of 3 years. Long tenure seems to be a very rare occurrence amongst this group of individuals. These figures are even worse among those who had come into employment after a spell of economic inactivity.

For some individuals, the current employment is their first one since they entered the labour market after leaving full-time education. Among the 173 men in the 'OLF category, 21 are such spells. Although these individuals ('first-timers') are included in the above table, the analyses presented in this paper treat them as different to the 'out of the labour force' (OLF) 
category. These men were in full-time education prior to the current spell of employment and thus have current employer tenure equal to labour market experience.

The variables which are commonly thought to have an effect on wages such as age, highest qualification, type of job, sector of the firm, firm size, union coverage etc. were included as controls. Descriptive statistics for all the variables used in the analyses are presented in Table 3. As expected, there are more men (i) aged less than 25, (ii) single, and (ii) with lower educational qualifications in the sample of men who had experienced an interruption prior to this employment compared to those who had not. These men also seem more likely to be working in private companies and doing manual jobs. In addition, it is not surprising that they are also less likely to have received any work-related training in the last 12 months.

The estimates of the log real hourly wage equations for various models estimated are summarised in Table 4. There are 7082 person-year observations used in the analysis of the wages. The previous labour market status variables are entered as dummies in Columns [1]. In this specification, the type of interruption the individual had prior to current employment is assumed to have a constant effect that persists over time, ceteris paribus.

The estimated returns to tenure are as expected. Base case is a man who has tenure of less than 1 year and has come from a previous employment into this employment. Relative to this individual, for a man who has been previously unemployed, the estimated wage penalty is about $8 \%$, ceteris paribus (Columns [1]). The individuals who had come from OLF state also fare very badly in terms of loss of wage compared to the base category. For these individuals, the penalty is about $9 \%$ lower, ceteris paribus. Excluding the controls not reported in the table did not change these estimates significantly.

Column [2] and [3] allow the effect of an interruption to vary with the interruption as well as with time since interruption. Time since interruption is the same as current employer tenure in these models. Unlike the model in Column [1], these models allow one to check 
whether the 'scarring effect' of a spell of interruption diminishes over time or not. When an individual enters employment after a spell of unemployment, he is estimated to earn about $6 \%$ less during his first year with the employer relative to someone who is also in his first year of employment but had come from another employment spell, ceteris paribus. ${ }^{20}$ This differential is estimated to increase over time up to about 4 years to a value of $14 \%$ and start to very slowly diminish after that. After 4 years with the current employer, the penalty is estimated to be about $12 \%$ (Column [2]). There is evidence to suggest that most of the individuals who experience unemployment go back to jobs that are unstable and of short duration (Boheim and Taylor (2000), Stewart (2000)). This implies that these scarred individuals never have an opportunity to recover from the loss by staying on with the same employer. This has important implications for labour market policies since the results imply that it is important to match individuals to good jobs and make sure that they do stay on in these jobs.

An individual coming after a spell of economic inactivity, is worse off initially in the first two years compared to someone coming after a spell of unemployment, but the scarring is estimated to diminish over time. In fact, after about three years with the same employer, the scarring effect has completely vanished. This is in contrast to someone whose previous spell was unemployment. ${ }^{21}$ Since some of this could be because of the small cell sizes involved in the OLF category, Column [3] looks at the effect of amalgamating the unemployment and out-of-the labour force statuses into one category of 'non-unemployment'. The estimated 'average scarring' effects in the first year is about $7 \%$ and thereafter it remains at about $10 \%$ regardless of time spent with the same employer. ${ }^{22}$

20 Gregory and Jukes estimated this penalty to be about $10 \%$ and Nickell et al (1999) estimated this to be about $12 \%$. But the definition of unemployment used in these two studies, refer to registered unemployment. The model specifications are slightly different in terms of the assumption made regarding the maximum length of time the unemployment is expected to have a differential effect. The sample periods used are also different.

21 Atkinson et al. (1996), from an employer recruitment survey, find that employers do pay attention to reasons for unemployment, frequency of unemployment spells, duration of unemployment, what the unemployed had been doing during the spell, etc. when faced with a job application form the unemployed.

22 This of course is constrained by the fact that very few men stay on with the same employer for longer than 5 years. 
As previously mentioned, a dummy for those individuals who entered this spell of employment straight after leaving full-time school ('first-timers') was entered in the regressions. Interpretation of the coefficient on this dummy is more complicated because by definition these individuals have zero experience at the start of their current spell. Therefore, this dummy is essentially picking up the effect of lack of previous experience for these individuals.

Full-time employment experience is included in all the regressions to pick up the returns to accumulated general human capital. The experience variable used is the total full-time employment experience coded as dummies. The estimated returns are as expected. Returns to experience was not found to be dependent on the previous labour market status (results not reported in the table).

Next, the models in Columns [1] and [2] are extended in Columns [4] and [5] respectively, to allow for the possibility of differential scarring effects by age and education. In Column [4], an individual aged less than 45 who has come into this employment via a spell of unemployment is estimated to incur a wage loss of about $6 \%$ relative to someone who has come from another employment spell, ceteris paribus. Bu if this individual had been aged over 45 and has had no educational qualifications, there is a massive additional scarring of $19 \%$ (Columns [4] and [5]). The estimated effect for under $45 \mathrm{~s}$ and over $45 \mathrm{~s}$ with some educational qualifications, are the same. That is, the additional scarring for over 45 is only present for individuals without any educational qualifications. Having an educational qualification here means having at least one 'Ordinary Level' qualification. No significant differential effects were found to exist for other age and other qualification groupings.

The estimated pattern of scarring associated with previous economic inactivity is very different to the one of previous unemployment. For example, in Column [4], an individual who is under 45 regardless of the qualifications possessed is estimated to sustain a wage loss of $6 \%$ if he came into this employment via a spell of inactivity relative to someone who had made an 
employment-to-employment transition, ceteris paribus. But, if this individual had been aged over 45 with some qualification, there is a massive additional loss of $38 \%$ at all levels of tenure.

In summary, an individual who has just experienced a spell of interruption prior to the current employment spell are estimated to be 'scarred' compared to an individual who had not. This 'scarring' effect is also estimated to persist over time. Even after working for 4 years with the same employers, they are still earning about $10 \%$ less relative to an otherwise equivalent individual who has come from another employment spell. In the case of men aged over 45, relative to men 45 and under, unemployment spell is associated with a wage loss of about $19 \%$ if these individuals do not have any qualifications. But in the case of economic inactivity, the wage loss for men aged over 45 relative to men 45 and under, the estimated wage loss is about 36$38 \%$, ceteris paribus, only if the individuals have some educational qualification.

Since the comparisons are made with an individual who has changed employment without an interruption, an interesting question to ask is whether it is possible to reduce the 'scarring' effect by changing employers without an interruption. This and some other related issues are addressed in the next section.

\section{MODEL EXTENSIONS}

Unlike most of the other data sets that have been used in the past to look at the effects on wages of individuals who have been displaced, the data set used in this study has some extra information about the interruption itself. In particular, the type of interruption, the length of interruption and also the number of previous spells of unemployment experienced by the individuals, are available. For most of the sample members, these are derived from information collected retrospectively. Given the possibility of recall errors, this information is used in an 'aggregate' manner to extend the previous analyses. The data also has many missing values. Instead of deleting observations with missing values, all the analyses were conducted with the inclusion of appropriate dummy variables for missing cases. The model presented in Column [3] 
of Table 4 was extended for these analyses and the results are presented in Table 6. Some relevant frequencies are presented in Table 5.

\section{Effect of an interruption caused by a redundancy}

The most important reason for leaving the last job was redundancy (Table 5). Of the 1348 men who were made redundant from their last job, $81 \%$ had managed to find employment without an intervening spell of 'non-employment'.

The estimated results that include a dummy for men who lost their last job because of redundancy are presented in Column [1] of Table 6. This dummy was also interacted with the dummy for individuals who had made a non-employment to employment transition. ${ }^{23}$ The estimated tenure effects are unchanged from previous analysis. The base case is a man who has made an employment-to-employment transition as well as those who had made a nonemployment-to-employment transition for 'non-redundancy' reasons. Most of these individuals voluntarily changed their employers. If the individual was made redundant and if he changed employers without an intervening spell of 'non-employment', then he is not 'scarred' by the redundancy. But if the individual was made redundant and he did not move into another job immediately, then it is estimated that this individual is less 'scarred' compared to someone who loses his job for 'other' reasons, ceteris paribus. This individual is expected to earn, on average, $5 \%$ more than an individual who loses his job for 'other' reasons and finds employment via a spell of non-employment. The scarring effect of the previous spell of 'non-employment' over time is slightly higher now compared to the model results presented in Column [3] of Table 4.

This is in contrast to results generally found in the literature on the effects of 'displacement' on subsequent earnings. This is not surprising for the following reasons. First, the literature on the effects of displacement generally looks at 'high' tenure individuals for whom

23 Inclusion of dummies for reasons such as termination of employment because (i) a temporary job came to an end, (ii) of dismissal, did not produce any significant results because of small cell sizes. 
this might matter. This distinction is not possible with this data set. Second, there is a period of notice that has to be given by the employer prior to making someone redundant (Borland et al (1997)), and some of these individuals are also eligible for redundancy payments and unemployment benefits. Individuals who quit their jobs voluntarily are disqualified from receiving benefits for up to 26 weeks. Given these reasons, it is possible that these individuals do start looking for a job early (because of the period of notice) and are able to wait until they find something suitable (because of redundancy payments). Unfortunately, information on whether the individuals who were made redundant received any redundancy payments and if they did then the amount they had received are not available in this data set. ${ }^{24}$

Another possible reason for the estimated results is that individuals who were made redundant were those possessing general skills and as a result the redundancy itself does not result in scarring due to loss of firm specific skills.

\section{Effect of the length of the interruption}

It is often believed that acquired human capital will depreciate during a spell of unemployment and the longer the interruption more the decline. As a result, many labour market policies have been aimed at preventing long spells of unemployment. In particular, there has been a programme of 'RESTART' in existence in this country since the 1986. Initially all individuals who have been unemployed for twelve months or more, and since 1987 all those who have been unemployed for six or more months have been invited for counselling. These individuals are then introduced to available training and support in order to match them into jobs that are better suited to their skills. But at the same time, benefit entitlements are also re-evaluated (Borland et al. (1997)). This important feature of the programme carries a threat element in the sense of benefits withdrawal if the individual does not attend the RESTART interview or if $s / h e$ is deemed not to be making genuine attempt to find a job. Dolton and O'Neill (1996) found that 
Restart interview scared individuals into signing-off and the timing of exits out of unemployment coincided with the first Restart interview. If individuals are put under a lot of pressure to find suitable employment and it might be the case that these individuals go into low-pay jobs. ${ }^{25}$ To see whether the length of the interruption has any effect on subsequent earnings, the base model (Column [3] Table 4) was re-estimated with the inclusion of four dummies for the length of the spell of interruption. To pick up the effect of RESTART spells longer than twelve months of duration were distinguished. The results from this extension are presented in Column [2] of Table 6. Unfortunately there was no information on the length of the interruption for just over half the sample members who had experienced an interruption (Table 5). Without omitting these cases, a dummy for missing values was included in all the regressions.

The base case here is an individual who has had an interruption that lasted for less than three months. No significant effect of the actual spell duration was found in addition to the incidence effect. Differentiating unemployment spells from those of economic inactivity also did not produce any significant effects via the spell duration, ceteris paribus. In contrast, Gregory and Jukes (1997) and Nickell et al (1999) found for Great Britain that long unemployment spells were associated with greater wage losses. A possible explanation for this contrasting result is that the unemployment variable used in these two studies refers to registered unemployment. It is possible that the negative effect found was due to the RESTART programme that is targeted at individuals who are signing on. The unemployment variable in this study includes both registered as well as unregistered unemployment and hence the estimated effects refer to the average over both types of spells.

\section{Effect of previous spells of unemployment}

Nearly $81 \%$ of those who had experienced a spell of interruption have also had another spell of unemployment prior to the last one (Table 5). Among the men who had moved to this spell of 
employment via another spell of employment without an interruption, $40 \%$ had had a spell of unemployment sometime in the past. The models estimated in the previous section directly compared individuals who made employment-to-employment transitions with those who made this transition via a spell of non-employment. If a spell of non-employment has a 'scarring' effect on subsequent earnings, an interesting question to ask is whether the 'scarring' effect can be negated earlier by changing your employer without an intervening spell of non-employment. Another way to pose this question is to ask whether a previous spell of unemployment still has an effect after a subsequent change in employer, or is it the case that only the immediately preceding spell of unemployment matters. ${ }^{26}$ The results of this investigation are presented in Column [3] of Table 6.

The base case is a man who made an employment-to-employment transition and who also has never been unemployed before, say Man1. Relative to this man, an individual who experiences unemployment for the first time prior to coming into this job (say Man2), is estimated to be worse off by about $20 \%$ on average. If Man1 had experienced an unemployment spell in the past, he is estimated to be worse off by about $9 \%$ in terms of loss of earnings. This is very similar to he figure estimated by Nickell et al. (1999). If Man2 has experienced another spell of unemployment prior to the last one, he is estimated to be less worse off in his current employment. In fact, the estimated scarring effect from repeat spells is only about $11 \%$, ceteris paribus. In summary, returns to tenure in the employment spell after the first spell of unemployment is the worst affected and the scarring effect of the interruption cannot be eliminated by making an employment-to-employment transition.

with a better worker-firm match in their subsequent job.

26 The model estimated looks at the effect of a previous spell of unemployment and not of 'non-employment'. The reason for this is that it was felt that it would not be correct to include spells of OLF where some included spells of education and training. 


\section{CONCLUSIONS}

This study has looked at the effects of an interruption on post-interruption wages for men using the first seven waves of the British Household Panel Survey (BHPS) conducted over the period 1991-1997. In particular, how the effect of an interruption on subsequent wages changes over time was addressed. The issue of sample selection and unobserved heterogeneity were also addressed in the analyses. The main findings of this study are:

(i) An unemployed individual when returning to work will earn about $6 \%$ less than an otherwise equivalent individual who has come from a spell of employment, during the first year of employment. It is estimated to increase from about $6 \%$ in the first year to about $14 \%$ in the fourth year, and then comes down to about $12 \%$ after that. It takes a very long time with the same employer to negate the earlier scarring effect.

(ii) If Men aged over 45 have no educational qualifications, they are estimated to be worse off by an additional $19 \%$ relative to men aged over 45 with some educational qualification and men under 45 , ceteris paribus. Estimated scarring effects did not depend on the possession of educational qualifications for the under $45 \mathrm{~s}$.

(iii) It is the first spell of unemployment that has the largest effect on subsequent wages. A man who goes into employment after experiencing his first unemployment spell is estimated to earn about $20 \%$ less relative to someone who has never experienced an unemployment spell. The estimated scarring effect from the second and subsequent unemployment spells is about $10 \%$.

(iv) Men who experience an interruption because of redundancy are found to be less scarred relative to men who have an interruption due to other reasons. Employment protection legislation requires the employers to give prior notice of termination. These individuals 
can therefore start to search for jobs while in employment. The existence of redundancy payments as well as being able to claim benefits without being disqualified from benefit receipts also must help these individuals to search better for a more suitable job. Redundancy may also be less stigmatising than dismissal or sacking.

(v) The study could not find any significant effects of the unemployment spell duration on subsequent wages, ceteris paribus, other than those coming via the incidence.

Active labour market policies such as training for the unemployed typically provide general rather than specific skills. In contrast, wage subsidies to employers to employ people from the unemployment stock assumes that the individuals would gain enough specific skills to make them employable without the subsidy. The above findings therefore have important policy implications. They imply that it is very important to make sure that unemployed individuals get matched properly into jobs that are stable and most suited for them in order to acquire suitable job specific skills. Special targeted measures for older men without any qualifications are very important. 


\section{REFERENCES}

Abraham, K. G. and Farber, H. S. (1987) - 'Job duration, seniority, and earnings', American Economic Review, 77(3), 278-297.

Altonji, J. G. and Shakotko, R. A. (1987) - 'Do wages rise with job seniority?', Review of Economic Studies, 54 (3), 437-459.

Altonji, J. G. and Williams, N. (1997) - 'Do wages rise with job seniority? A reassessment', mimeo, paper presented at the Society of Labor Economists meeting held in Washington D.C., USA, 1997.

Arulampalam, W., Booth, A. L. and Taylor, M. P. (2000) - 'Unemployment persistence', $\underline{\text { Oxford }}$ Economic Papers, 52, 24-50.

Atkinson, J., Giles, L. and Meager, N. (1996) - Employers, Recruitment and the Unemployed, IES (Institute for Employment Studies, UK.) Report 325, ISBN 1-85184-253-5.

Boheim, R. and Taylor, M. P. (2000) - 'The search for success: do the unemployed find stable employment?', Programme on Labour Market Dynamics in a Changing Environment, Discussion paper no. 00/52, University of Essex.

Borland, J, Gregg, P, Knight, G. and Wadsworth, J. (1998) - 'They get knocked down. Do they get up again? Displaced workers in Britain and Australia', mimeo.

Dolton, P. and O'Neill, D. (1996) - 'Unemployment duration and the Restart effect: some experimental evidence', The Economic Journal, Vol. 106, no. 435, 387-400.

Dustmann, C and Meghir, C. (1998) - 'Wages, experience and seniority', mimeo, University College, London.

Fallick, B.C. (1996) - 'A review of the recent empirical literature on displaced workers', Industrial and Labor Relations Review, 50 (1), 5-16.

Gregg, P. and Wadsworth (1996) - 'Mind the gap, please? The changing nature of entry jobs in Britain', Centre for Economic Performance, Discussion Paper No. 303, London School of Economics, forthcoming, Economica.

Gregory, M. and Jukes, R. (1997) - 'The effects of unemployment on subsequent earnings: A study of British Men 1984-94', The Labour Market Consequences of Technical and Structural Change, DP no. 21. 
Jacobson, L., LaLonde, R., and Sullivan, D. (1993) - 'Earnings losses of displaced workers', American Economic Review, 83, 685-709.

Kletzer, L. G. (1998) - 'Job displacement', Journal of Economic Perspectives, 12 (1), 115-136.

Lockwood, B. (1991) -'Information externalities in the labour market and the duration of unemployment', Review of Economic Studies, 58 (4), 733-753.

Narendranathan, W. and Elias, P. (1993) - 'Influences of past history on the incidence of youth unemployment: Empirical findings for the UK', Oxford Bulletin of Economics and Statistics, 55, no. 2, 161-186.

Nickell, S.J., Jones, T. and Quintini, G. (1999) - 'A Picture of the job insecurity facing British Men', Centre for Economic Perfomance, London School of Economics, The Labour Market Consequences of Technical and Structural Change Discussion Paper No. 42.

Paull, G. (1997) - 'Dynamic labour market behaviour in the British Household Panel Survey: the effects of recall bias and panel attrition', The Labour Market Consequence of Technical and Structural Change Discussion Paper no. 10, CEP, London School of Economics.

Pissarides, C. (1992) - 'Loss of skill during unemployment and the persistence of employment shocks', Quarterly Journal of Economics, 107, 1371-1391.

Stevens, A. H. (1997) - 'Persistent effects of job displacement: the importance of multiple job losses', Journal of Labor Economics, 15(1), 165-188.

Stewart, M. B. (2000) - 'The inter-related dynamics of unemployment and low pay', University of Warwick, mimeo.

Taylor, M. F. (1996) (Ed. with J Brice et al) British Household Panel Survey User Manual Volumes A and B, Wivenhoe Park: University of Essex.

Topel, R. (1991) - 'Specific capital, mobility and wages: wages rise with job seniority', Journal of Political Economy, 99 (1), 145-176. 


\section{TABLE 1}

\begin{tabular}{|c|c|c|c|c|c|c|c|c|}
\hline $\begin{array}{l}\text { Total number of } \\
\text { employment observations }\end{array}$ & \multicolumn{8}{|c|}{$\begin{array}{l}\text { Total number of direct interviews } \\
\text { (Column percentage) }\end{array}$} \\
\hline & Wave 1 & Wave 2 & Wave 3 & Wave 4 & Wave 5 & Wave 6 & Wave 7 & Total \\
\hline Less than 2 & $334(100)$ & $119(50.0)$ & $64(39.5)$ & $49(30.6)$ & $37(25.2)$ & $68(26.6)$ & $423(20.6)$ & 1094 (32.6) \\
\hline 2 or more & & $119(50.0)$ & $98(60.5)$ & $111(69.4)$ & $110(74.8)$ & $188(73.4)$ & $1632(79.4)$ & $2258(67.4)$ \\
\hline Total & 334 & 238 & 162 & 160 & 147 & 256 & 2055 & 3352 \\
\hline & \multicolumn{8}{|c|}{$\begin{array}{l}\text { Total number of direct continuous interviews from } 1991 \text { (wave 1) } \\
\text { (Column percentage) }\end{array}$} \\
\hline Less than 2 & 494(100.0) & $203(62.7)$ & $77(46.7)$ & $74(45.4)$ & $27(36.5)$ & $23(29.9)$ & 423 (20.6) & $1321(39.4)$ \\
\hline 2 or more & 0 & $121(37.3)$ & $88(53.3)$ & $89(54.6)$ & $47(63.5)$ & $54(70.1)$ & $1632(79.4)$ & $2031(60.6)$ \\
\hline Total & 494 & 324 & 165 & 163 & 74 & 77 & 2055 & 3352 \\
\hline
\end{tabular}

TABLE 2

\begin{tabular}{|c|c|c|c|}
\hline \multirow[t]{2}{*}{ Employer tenure } & \multicolumn{3}{|c|}{ Previous spell } \\
\hline & $\begin{array}{c}\text { Employment } \\
{[\mathrm{Col} \%]}\end{array}$ & $\begin{array}{c}\text { Unemployment } \\
{[\mathrm{Col} \%]}\end{array}$ & $\frac{\text { Out of the labour }}{\text { force }}$ \\
\hline Less than one year & $802 \quad[12.6]$ & $226[41.2]$ & $\begin{array}{ll}65 & {[37.6]}\end{array}$ \\
\hline 1 to 2 years & $410 \quad[6.5]$ & $137 \quad[25.0]$ & $42 \quad[24.3]$ \\
\hline 2 to 3 years & $303 \quad[4.8]$ & $79[14.4]$ & $21 \quad[12.1]$ \\
\hline 3 to 4 years & $244 \quad[3.8]$ & $47 \quad[8.6]$ & $11 \quad[6.4]$ \\
\hline 4 to 5 years & $240 \quad[3.8]$ & {$[5.1]$} & [4.6] \\
\hline 5 to 10 years & $1172[18.4]$ & [4.4] & [8.1] \\
\hline 10 or more years & $3189 \quad[50.1]$ & [1.5] & [6.9] \\
\hline TOTAL & $\begin{array}{c}6360 \\
{[89.8 \% \text { of total }]}\end{array}$ & $\begin{array}{c}549 \\
{[7.8 \% \text { of total }]}\end{array}$ & $\begin{array}{c}173 \\
\text { [ } 2.4 \% \text { of total] }\end{array}$ \\
\hline
\end{tabular}

Notes: $1 . \quad 7082$ person-observations in total 1991-1997.

2. 'Out-of-the-labour-force' category includes men who were in full-

time education prior to this spell of employment. 
Table 3 - Descriptive statistics by previous labour market status 1991-1997 [Mean (Std. Deviation)]

\begin{tabular}{|c|c|c|}
\hline Variables & \multicolumn{2}{|c|}{ Previous Labour Market Status } \\
\hline & Employment & Non-employment \\
\hline \multicolumn{3}{|l|}{ Personal Characteristics } \\
\hline Age $\quad 25-34$ & 0.31 & 0.29 \\
\hline $35-44$ & 0.33 & 0.25 \\
\hline $45+$ & 0.30 & 0.27 \\
\hline Married & 0.80 & 0.65 \\
\hline Spouse is in employment & 0.59 & 0.40 \\
\hline Has dependent children & 0.44 & 0.34 \\
\hline School type & 0.07 & 0.05 \\
\hline Grammar no fee & 0.16 & 0.11 \\
\hline Highest qualification - Degree & 0.16 & 0.13 \\
\hline - Other higher (teaching, nursing, etc) & 0.30 & 0.25 \\
\hline -A' Levels or equivalent & 0.13 . & 0.18 \\
\hline - 'O' Levels or equivalent & 0.19 & 0.20 \\
\hline Has completed an apprenticeship & 0.02 & 0.02 \\
\hline Housing Tenure $\quad$ Owns outright & 0.09 & 0.16 \\
\hline Has a mortgage & 0.75 & 0.59 \\
\hline Council tenant & 0.08 & 0.16 \\
\hline Health disability affects work & 0.06 & 0.09 \\
\hline Registered disabled & 0.01 & 0.01 \\
\hline \multicolumn{3}{|l|}{ Job and Workplace Characteristics } \\
\hline Working in a Public Company & 0.24 & 0.15 \\
\hline Working for a Charity & 0.02 & 0.01 \\
\hline Workplace size - 50-99 employees & 0.13 & 0.13 \\
\hline $100-199$ employees & 0.14 & 0.09 \\
\hline$>=200$ employees & 0.36 & 0.27 \\
\hline Had work-related training in the last 12 months & 0.37 & 0.23 \\
\hline Workplace union presence & 0.56 & 0.41 \\
\hline Current job is part-time & 0.02 & 0.09 \\
\hline Job - Professional/Managerial & 0.44 & 0.26 \\
\hline Skilled non-manual & 0.13 & 0.12 \\
\hline Skilled manual & 0.30 & 0.37 \\
\hline Semi-skilled manual & $0.11 \ldots \ldots$ & $0.21 \ldots$ \\
\hline Current Employer Tenure - months & $144.00(119)$ & $25.00(35)$ \\
\hline Full-time experience - months & $194.00(143)$ & $140.00(151)$ \\
\hline \multicolumn{3}{|l|}{ Industrial affiliation } \\
\hline Energy and Water Supplies (11 to 17) & 0.04 & 0.01 \\
\hline Extraction of Minerals etc. Manufacture of metals (22 to 26$)$ & 0.05 & 0.05 \\
\hline Metal Goods, Engineering \& Vehicles (31 to 37) & 0.15 & 0.15 \\
\hline Other Manufacturing (41 to 49) & 0.13 & 0.15 \\
\hline Construction (50) & 0.04 & 0.07 \\
\hline Distribution, Hotels \& Catering, Repairs (61 to 67) & 0.13 & 0.18 \\
\hline Transport \& Communication (71 to 79) & 0.10 & 0.10 \\
\hline Banking, Finance et. (81 to 85) & 0.12 & 0.12 \\
\hline Other Services (91 to 99$)$ & 0.23 . & 0.18 \\
\hline Hourly Wage (1991 prices) & $8.74(5.6)$ & $5.83(3.99)$ \\
\hline Weekly hours & $43.41(9.3)$ & $37.89(9.1)$ \\
\hline Sample Size- person year observations & 6380 & 702 \\
\hline
\end{tabular}


Table 4 - Log Real Hourly Wage Equations for Men 1991-1997

Within-Group Coefficient Estimates (Robust Std. Errors)

\begin{tabular}{|c|c|c|c|c|c|}
\hline & [1] & [2] & [3] & [4] & [5] \\
\hline Tenure in current emp - base is $<1$ year & & & & & \\
\hline $1-2$ years & $0.018(0.011)$ & $0.026(0.013)^{* *}$ & $0.026(0.013)^{* *}$ & $0.020(0.011)^{*}$ & $0.026(0.013)^{*}$ \\
\hline $2-3$ years & $0.014(0.013)$ & $0.021(0.015)$ & $0.021(0.015)$ & $0.016(0.013) * *$ & $0.020(0.015)$ \\
\hline $3-4$ years & $0.031(0.015)^{* *}$ & $0.042(0.016)^{* *}$ & $0.038(0.017)^{* *}$ & $0.032(0.015)^{* *}$ & $0.042(0.016)^{* *}$ \\
\hline $4-5$ years & $0.048(0.016)^{* *}$ & $0.053(0.017)^{* *}$ & $0.055(0.017)^{* *}$ & $0.048(0.016)^{* *}$ & $0.051(0.017)^{* *}$ \\
\hline $5-10$ years & $0.056(0.013)^{* *}$ & $0.061(0.013) * *$ & $0.062(0.013)^{* *}$ & $0.056(0.013) * *$ & $0.058(0.013)^{* *}$ \\
\hline$>10$ years & $0.087(0.014)^{* *}$ & $0.090(0.015)^{* *}$ & $0.091(0.015)^{* *}$ & $0.084(0.014)^{* *}$ & $0.086(0.015)^{* *}$ \\
\hline $\begin{array}{l}\text { Previous labour market status - } \\
\text { unemployment }\end{array}$ & $-0.076(0.017)^{* *}$ & & & $-0.061(0.019) * *$ & \\
\hline And Age $>45$ & & & & $-0.187(0.054)^{* *}$ & $-0.184(0.054)^{* *}$ \\
\hline And Age $>45$ and has quals & & & & $0.187(0.062)^{* *}$ & $0.190(0.062)^{* *}$ \\
\hline Other & $-0.093(0.027)^{* *}$ & & & $-0.079(0.030)^{* *}$ & \\
\hline And Age > 45 & & & & $0.139(0.093)$ & $0.131(0.094)$ \\
\hline And Age $>45$ and has quals & & & & $-0.381(0.119)^{* *}$ & $-0.360(0.121)^{* *}$ \\
\hline $\begin{array}{l}\text { Came from } \mathrm{u} / \mathrm{e}-\text { time since interruption } \\
<1 \text { year }\end{array}$ & & $-0.061(0.020)^{* *}$ & & & $-0.049(0.021)^{* *}$ \\
\hline $1-2$ years & & $-0.073(0.025)^{* *}$ & & & $-0.058(0.027)^{* *}$ \\
\hline $2-3$ years & & $-0.095(0.031)^{* *}$ & & & $-0.076(0.033)^{* *}$ \\
\hline $3-4$ years & & $-0.143(0.039)^{* *}$ & & & $-0.131(0.040)^{* *}$ \\
\hline$>4$ years & & $-0.116(0.040)^{* *}$ & & & $-0.093(0.043)^{* *}$ \\
\hline $\begin{array}{l}\text { Came from other state }- \text { time since } \\
\text { interruption }\end{array}$ & & $-0.075(0.034)^{* *}$ & & & $-0.070(0.037)^{*}$ \\
\hline $1-2$ years & & $-0.180(0.043)^{* *}$ & & & $-0.157(0.045)^{* *}$ \\
\hline $2-3$ years & & $-0.107(0.058)^{* *}$ & & & $-0.077(0.060)$ \\
\hline$>3$ years & & $0.006(0.051)$ & & & $0.020(0.053)$ \\
\hline $\begin{array}{l}\text { Came from non-employment } \\
\text { since interruption } \quad<1 \text { year }\end{array}$ & & & $-0.065(0.018)^{* *}$ & & \\
\hline $1-2$ years & & & $-0.095(0.023)^{* *}$ & & \\
\hline $2-3$ years & & & $-0.095(0.029)^{* *}$ & & \\
\hline $3-4$ years & & & $-0.094(0.035)^{* *}$ & & \\
\hline$>4$ years & & & $-0.101(0.035)^{* *}$ & & \\
\hline
\end{tabular}


Table 4 - Continued

\begin{tabular}{|c|c|c|c|c|c|}
\hline & {$[1]$} & {$[2]$} & [3] & [4] & [5] \\
\hline Current employment is first & $-0.174(0.058)^{* *}$ & $-0.175(0.058)^{* *}$ & $-0.170(0.058)^{* *}$ & $-0.174(0.058)^{* *}$ & $-0.175(0.058)^{* *}$ \\
\hline $\begin{array}{r}\text { Full-time experience (months)- } \\
1-2 \text { years }\end{array}$ & $0.002(0.017)$ & $0.004(0.017)$ & $0.004(0.017)$ & $0.002(0.017)$ & $0.002(0.017)$ \\
\hline $2-5$ years & $0.017(0.015)$ & $0.018(0.015)$ & $0.019(0.015)$ & $0.017(0.015)$ & $0.018(0.015)$ \\
\hline $5-10$ years & $0.073(0.020)^{* *}$ & $0.075(0.020)^{* *}$ & $0.075(0.020)^{* *}$ & $0.072(0.020)^{* *}$ & $0.074(0.020)^{*}$ \\
\hline more than 10 years & $0.119(0.024)^{* *}$ & $0.122(0.024)^{* *}$ & $0.121(0.024)^{* *}$ & $0.117(0.024)^{* *}$ & $0.120(0.024)$ ** \\
\hline Adjusted $\mathrm{R}^{2}$ & 0.916 & 0.916 & 0.916 & 0.917 & 0.917 \\
\hline
\end{tabular}

NOTES:

1. Number of observations - person years $=7082$. The sample consists of all men who were continuously interviewed (until they exit) and were found to be in employment at least twice over the period 1991 - 1997. Time since interruption is the same as current employer tenure.

2. All specifications, in addition to the above, also include age dummies, time dummies, and a correction for selectivity interacted with time dummies - see text for details.

3. + Full set of control variables are (in addition to note 2 above): Marital status, Health Disability, Temporary/Fixed term contract, Part-time job, Employment sector, Firm size, Received training in current job, Job type, Regional dummies and Industry dummies. See Appendix for further details.

4. ** - significant at $5 \%$ or less; * - significant at $10 \%$. 
$\underline{\text { Table } 5 \text { - Frequencies }}$

\begin{tabular}{|c|c|c|}
\hline & \multicolumn{2}{|c|}{ Previous Labour Market Status } \\
\hline & $\begin{array}{l}\text { Employment } \\
\text { [\% of } 6380]\end{array}$ & $\begin{array}{c}\text { Non-employment } \\
\text { [\% of 702] }\end{array}$ \\
\hline \multicolumn{3}{|c|}{ 1. Reason for leaving previous job } \\
\hline Made Redundant & $1085[17.0]$ & $263[37.5]$ \\
\hline Sacked/dismissed & $144[2.3]$ & $20[2.9]$ \\
\hline Temporary job ended & $234[3.7]$ & $61[8.7]$ \\
\hline Missing & $378[5.9]$ & $111[15.8]$ \\
\hline \multicolumn{3}{|c|}{ 2. Length of previous interruption } \\
\hline Less than 3 months & & $57[8.1]$ \\
\hline 3 to 6 months & & $68[9.7]$ \\
\hline 6 to 9 months & & $37[5.3]$ \\
\hline 9 to 12 months & & $43[6.1]$ \\
\hline More than 12 months & & $103[14.7]$ \\
\hline Missing & & $394[56.1]$ \\
\hline \multicolumn{3}{|c|}{$\underline{3 . ~ H a s ~ h a d ~ a ~ s p e l l ~ o f ~ u n e m p l o y m e n t ~}^{+}$} \\
\hline $\begin{array}{l}\text { One or more previous } \\
\text { unemployment spells }\end{array}$ & $2567[40.2]$ & $567[80.8]$ \\
\hline Missing & $5[0.00]$ & $60[8.6]$ \\
\hline
\end{tabular}

Notes:

1. Number of Employment-to-employment transitions $=6380$;

Number of Non-employment-to-employment transitions $=702$.

2. ${ }^{+}$For the unemployed, this is in addition to the spell of unemployment under consideration as an interruption. 


\section{Table 6 - Log Real Hourly Wage Equations for Men 1991-1997 Within-Group Coefficient Estimates (Robust Std. Errors) Model Extensions}

\begin{tabular}{|c|c|c|c|}
\hline & [1] & {$[2]$} & [3] \\
\hline \multicolumn{4}{|l|}{ Tenure in current emp - base is $<1$ year } \\
\hline $1-2$ years & $0.026(0.013)^{* *}$ & $0.026(0.013)^{* *}$ & $0.026(0.013)^{*}$ \\
\hline $2-3$ years & $0.021(0.015)$ & $0.020(0.015)$ & $0.018(0.015)$ \\
\hline 3 - 4 years & $0.038(0.017)^{* *}$ & $0.036(0.017)^{* *}$ & $0.034(0.017)^{* *}$ \\
\hline $4-5$ years & $0.055(0.017)^{* *}$ & $0.053(0.017)^{* *}$ & $0.049(0.017)^{* *}$ \\
\hline $5-10$ years & $0.062(0.015)^{* *}$ & $0.060(0.014) * *$ & $0.057(0.014) * *$ \\
\hline more than 10 years & $0.092(0.015)^{* *}$ & $0.090(0.015)^{* *}$ & $0.084(0.017)^{* *}$ \\
\hline \multicolumn{4}{|l|}{$\begin{array}{l}\text { Non-employment and time since } \\
\text { interruption interaction }\end{array}$} \\
\hline <1 year... & $-0.085(0.022) * *$ & $-0.062(0.020) * *$ & $-0.193(0.032)^{* *}$ \\
\hline $1-2$ years & $-0.112(0.026)^{* *}$ & $-0.092(0.025)^{* *}$ & $-0.218(0.035)^{* *}$ \\
\hline $2-3$ years & $-0.117(0.032)^{* *}$ & $-0.091(0.030)^{* *}$ & $-0.215(0.038) * *$ \\
\hline $3-4$ years & $-0.118(0.038)^{* *}$ & $-0.091(0.037)^{* *}$ & $-0.214(0.043)^{* *}$ \\
\hline$>4$ years & $-0.115(0.038)^{* *}$ & $-0.098(0.037)^{* *}$ & $-0.206(0.043) * *$ \\
\hline Was made redundant in last employment & $0.017(0.024)$ & & \\
\hline $\begin{array}{l}\text { Was made redundant and had a spell of } \\
\text { non-employment. }\end{array}$ & $0.053(0.030)^{*}$ & & \\
\hline $\begin{array}{l}\text { Previous non-employment } * \text { non- } \\
\text { employment spell duration } \\
>=3 \text { and }<6 \text { months }\end{array}$ & & $-0.008(0.040)$ & \\
\hline$>=6$ and $<9$ months & & $-0.016(0.070)$ & \\
\hline$>=9$ and $<12$ months & & $-0.004(0.063)$ & \\
\hline$>=12$ months & & $0.002(0.039)$ & \\
\hline One or more spell of unemployment ${ }^{+}$ & & & $-0.091(0.026)^{* *}$ \\
\hline $\begin{array}{l}\text { One or more spell of unemployment and } \\
\text { previous spell is non-employment }\end{array}$ & & & $0.183(0.035)^{* *}$ \\
\hline Adjusted $\mathrm{R}^{2}$ & 0.916 & 0.916 & 0.917 \\
\hline
\end{tabular}

Notes:

1. See notes to Table 4. These are extensions to model in Column [3] of Table 4.

2. In addition to all the previous variables, these models also have a dummy for cases with missing information on the reason for leaving previous employment in Column [1], a dummy for cases with missing previous labour market status duration in Column [2], and a dummy for cases with missing number of previous spells of unemployment in Column [3].

3. ${ }^{+}$For the individuals who were unemployed in the previous state, one or more spell means that they have had at least one other spell of unemployment prior to the last one. 
Appendix:

Table A1: Sample Selection Probit

\begin{tabular}{|l|c|}
\hline Variables & $\begin{array}{c}\text { Coefficient } \\
\text { estimate } \\
\text { (std. error) }\end{array}$ \\
\hline Intercept & $-0.585(0.179)^{* *}$ \\
Age 25-34 & $0.067(0.072)$ \\
Age 35-44 & $-0.022(0.080)$ \\
Age 45 and over & $-0.143(0.085)^{*}$ \\
White & $0.404(0.11)^{* *}$ \\
Married & $-0.005(0.086)$ \\
Spouse employed & $0.211(0.064)^{* *}$ \\
Has children (dummy) & $-0.562(0.261)^{* *}$ \\
Married*children dummy & $0.540(0.268)^{* *}$ \\
Registered Disabled & $-0.433(0.172)^{* *}$ \\
Has a disability that affects the type of work the individual does & $-0.334(0.087)^{* *}$ \\
Highest Qualifications held Degree & $0.590(0.099)^{* *}$ \\
Other Higher Qualifications (Nursing, Teaching etc.) & $0.314(0.075)^{* *}$ \\
'A' Levels and equivalent & $0.361(0.081)^{* *}$ \\
'O' Levels and equivalent & $0.153(0.072)^{* *}$ \\
Other Qualifications & $0.246(0.102)^{* *}$ \\
(Base is no qualifications) & \\
Has completed an Apprenticeship & $-0.060(0.143)$ \\
Type of School Attended - last Private & $-0.166(0.099)^{*}$ \\
Grammar - no fee & $-0.013(0.076)$ \\
Technical School & $0.041(0.085)$ \\
Housing Tenure $\quad$ Owner - no mortgage & $0.112(0.097)$ \\
Owner - has a mortgage & $0.273(0.075)^{* *}$ \\
Council House Renter & $0.012(0.092)$ \\
Unemployment Rate - Travel to Work Area - \% & $-0.830(1.203)$ \\
Father's occupation - non manual when aged 14 & $0.064(0.081)$ \\
Father's occupation - skilled manual when aged 14 & $0.081(0.059)$ \\
Father's occupation - unskilled manual when aged 14 & $0.209(0.080)^{* *}$ \\
Father's occupation - self employed when aged 14 & $-0.188(0.071)^{* *}$ \\
\hline Maximised Log Likelihood values & -2110.63 \\
Restricted Log likelihood & -2243.87 \\
Zavoina-McKelvey Pseudo- R-squared & 0.422 \\
No. of Observations & 3347 \\
\hline Nit Reg & \\
\hline
\end{tabular}

Notes: (i) Regional dummies included. All variables refer to 1991 wave.

(ii) The dependent variable takes the value of 1 if the individual was continuously interviewed until he exits and was found to be in employment in at least two waves over the period 1991 1997.

(iii) $*$,** Coefficient significant at 10 and $5 \%$ respectively. 


\section{IZA Discussion Papers}

\begin{tabular}{|c|c|c|c|c|}
\hline No. & Author(s) & Title & Area & Date \\
\hline 91 & M. Lechner & $\begin{array}{l}\text { Identification and Estimation of Causal Effects of } \\
\text { Multiple Treatments Under the Conditional } \\
\text { Independence Assumption }\end{array}$ & 6 & $12 / 99$ \\
\hline 92 & R. E. Wright & The Rate of Return to Private Schooling & 5 & $12 / 99$ \\
\hline 93 & M. Lechner & $\begin{array}{l}\text { An Evaluation of Public-Sector-Sponsored } \\
\text { Continuous Vocational Training Programs in East } \\
\text { Germany }\end{array}$ & 6 & $12 / 99$ \\
\hline 94 & $\begin{array}{l}\text { M. Eichler } \\
\text { M. Lechner }\end{array}$ & $\begin{array}{l}\text { An Evaluation of Public Employment Programmes } \\
\text { in the East German State of Sachsen-Anhalt }\end{array}$ & 6 & $12 / 99$ \\
\hline 95 & $\begin{array}{l}\text { P. Cahuc } \\
\text { A. Zylberberg }\end{array}$ & Job Protection, Minimum Wage and Unemployment & 3 & $12 / 99$ \\
\hline 96 & $\begin{array}{l}\text { P. Cahuc } \\
\text { A. Zylberberg }\end{array}$ & $\begin{array}{l}\text { Redundancy Payments, Incomplete Labor } \\
\text { Contracts, Unemployment and Welfare }\end{array}$ & 3 & $12 / 99$ \\
\hline 97 & A. Barrett & $\begin{array}{l}\text { Irish Migration: Characteristics, Causes and } \\
\text { Consequences }\end{array}$ & 1 & $12 / 99$ \\
\hline 98 & $\begin{array}{l}\text { J.P. Haisken-DeNew } \\
\text { C. M. Schmidt }\end{array}$ & $\begin{array}{l}\text { Industry Wage Differentials Revisited: A } \\
\text { Longitudinal Comparison of Germany and USA }\end{array}$ & $1 / 5$ & $12 / 99$ \\
\hline 99 & R. T. Riphahn & $\begin{array}{l}\text { Residential Location and Youth Unemployment: } \\
\text { The Economic Geography of School-to-Work- } \\
\text { Transitions }\end{array}$ & 1 & $12 / 99$ \\
\hline 100 & $\begin{array}{l}\text { J. Hansen } \\
\text { M. Lofstrom }\end{array}$ & $\begin{array}{l}\text { Immigrant Assimilation and Welfare Participation: } \\
\text { Do Immigrants Assimilate Into or Out-of Welfare? }\end{array}$ & $1 / 3$ & $12 / 99$ \\
\hline 101 & $\begin{array}{l}\text { L. Husted } \\
\text { H. S. Nielsen } \\
\text { M. Rosholm } \\
\text { N. Smith }\end{array}$ & $\begin{array}{l}\text { Employment and Wage Assimilation of Male First } \\
\text { Generation Immigrants in Denmark }\end{array}$ & 3 & $1 / 00$ \\
\hline 102 & $\begin{array}{l}\text { B. van der Klaauw } \\
\text { J. C. van Ours }\end{array}$ & $\begin{array}{l}\text { Labor Supply and Matching Rates for Welfare } \\
\text { Recipients: An Analysis Using Neighborhood } \\
\text { Characteristics }\end{array}$ & $2 / 3$ & $1 / 00$ \\
\hline 103 & K. Brännäs & $\begin{array}{l}\text { Estimation in a Duration Model for Evaluating } \\
\text { Educational Programs }\end{array}$ & 6 & $1 / 00$ \\
\hline 104 & S. Kohns & $\begin{array}{l}\text { Different Skill Levels and Firing Costs in a } \\
\text { Matching Model with Uncertainty - } \\
\text { An Extension of Mortensen and Pissarides (1994) }\end{array}$ & 1 & $1 / 00$ \\
\hline 105 & $\begin{array}{l}\text { G. Brunello } \\
\text { C. Graziano } \\
\text { B. Parigi }\end{array}$ & $\begin{array}{l}\text { Ownership or Performance: What Determines } \\
\text { Board of Directors' Turnover in Italy? }\end{array}$ & 1 & $1 / 00$ \\
\hline
\end{tabular}


1979 - 1990: An analysis of the (West-)German multivariate failure times and unobserved heterogeneity

107 J. C. van Ours G. Ridder

J. Boone

J. C. van Ours

109 G. J. van den Berg

B. van der Klaauw

110 D. DeVoretz

C. Werner

111 V. Sorm

K. Terrell

112

L. Bellmann

T. Schank

113 R. Euwals

114 G. Brunello

A. Medio

115 A. Cigno

F. C. Rosati

116

C. Belzil

S. Bender

A. Haas

C. Klose

118 M. A. Shields

M. E. Ward

119 A. Lindbeck

D. J. Snower

120 P. T. Pereira

P. S. Martins

121

J. C. van Ours

122

D. Munich

J. Svejnar

K. Terrell

123 J. Hunt
Fast Track or Failure: A Study of the Completion

Rates of Graduate Students in Economics

Modeling Financial Incentives to Get Unemployed Back to Work

Combining Micro and Macro Unemployment

Duration Data

A Theory of Social Forces and Immigrant Second

Language Acquisition

Sectoral Restructuring and Labor Mobility:

A Comparative Look at the Czech Republic

Innovations, Wages and Demand for

5

$1 / 00$

Heterogeneous Labour: New Evidence from a

Matched Employer-Employee Data-Set

Do Mandatory Pensions Decrease Household

Savings? Evidence for the Netherlands

An Explanation of International Differences in

Education and Workplace Training

Why do Indian Children Work, and is it Bad for

3

$2 / 00$

Them?

Unemployment Insurance and Subsequent Job

Duration: Job Matching vs. Unobserved

Heterogeneity

IAB Employment Subsample 1975-1995.

Opportunities for Analysis Provided by the

Anonymised Subsample

Improving Nurse Retention in the British National

Health Service: The Impact of Job Satisfaction on

5

$2 / 00$

Intentions to Quit

The Division of Labor and the Market for

Organizations

Does Education Reduce Wage Inequality?

Quantile Regressions Evidence from Fifteen

European Countries

3

$2 / 00$

$2 / 00$

Do Active Labor Market Policies Help Unemployed $\quad 4 / 6 \quad 3 / 00$

Workers to Find and Keep Regular Jobs?

Returns to Human Capital under the Communist

Wage Grid and During the Transition to a Market

4

$3 / 00$

Economy

Why Do People Still Live in East Germany? 
125 F. Büchel of Social Assistance Benefits

J. R. Frick

The Income Portfolio of Immigrants in Germany $1 / 3$

$3 / 00$

Effects of Ethnic Origin and Assimilation. Or:

Who Gains from Income Re-Distribution?

126 J. Fersterer

Smoking, Discount Rates, and Returns to

R. Winter-Ebmer

Education

127 M. Karanassou

Characteristics of Unemployment Dynamics: The

Chain Reaction Approach

D. J. Snower

Do Unemployment Insurance Recipients Actively

Seek Work? Evidence From Randomized Trials in

Four U.S. States

129 B. R. Chiswick

M. E. Hurst

The Employment, Unemployment and

Unemployment Compensation Benefits of

Immigrants

130 G. Brunello

S. Comi

C. Lucifora

The Returns to Education in Italy: A New Look at

5

$3 / 00$

the Evidence

131 B. R. Chiswick

132

R. A. Hart

Are Immigrants Fa

Hours and Wages in the Depression: British 7

133 D. N. F. Bell

Paid and Unpaid Overtime Working in Germany and 1

R. A. Hart

O. Hübler

W. Schwerdt

the UK

134 A. D. Kugler

G. Saint-Paul

135 A. Barrett

P. J. O'Connell

136 M. Bräuninger

M. Pannenberg

Hiring and Firing Costs, Adverse Selection and

3

$3 / 00$

Long-term Unemployment

Is There a Wage Premium for Returning Irish

$3 / 00$

Migrants?

Unemployment and Productivity Growth: An

$3 / 00$

Empirical Analysis within the Augmented Solow

3

Model

137 J.-St. Pischke

Continuous Training in Germany

138 J. Zweimüller

R. Winter-Ebmer

Firm-specific Training: Consequences for Job

Mobility

139 R. A. Hart

Y. Ma

Wages, Hours and Human Capital over the

$3 / 00$

140 G. Brunello

Life Cycle

1

Education and Earnings Growth: Evidence from $11 \quad$ 2/5 4/00

S. Comi

European Countries

141 R. Hujer

M. Wellner

The Effects of Public Sector Sponsored Training on

Individual Employment Performance in East

6

$4 / 00$

Germany 

both Worlds?

Does the Recent Success of Some OECD Countries in Lowering their Unemployment Rates Lie in the Clever Design of their Labour Market Reforms?

Employment Effects of Labour Taxation in an Efficiency Wage Model with Alternative Budget Constraints and Time Horizons

149 R. Lalive

J. C. van Ours

J. Zweimüller

150 J. DiNardo

K. F. Hallock

J.-St. Pischke

$151 \quad$ M. Ward

152 J. J. Dolado

F. Felgueroso

J. F. Jimeno

153 A. S. Kalwij

M. Gregory

154 M. Gerfin

M. Lechner

155 J. Hansen

156 C. Dustmann

F. Fabbri

157 P. Apps

R. Rees

158 A. Björklund

T. Eriksson

M. Jäntti

O. Raaum

E. Österbacka

The Impact of Active Labor Market Programs and Benefit Entitlement Rules on the Duration of

Unions and the Labor Market for Managers

Gender, Salary and Promotion in the Academic Profession

The Role of the Minimum Wage in the Welfare 3

Microeconometric Evaluation of the Active Labour 6

The Duration of Immigrant
Evidence from Sweden

Language Proficiency and Labour Market Per- 1

formance of Immigrants in the UK

Household Production, Full Consumption and $\quad 7$ the Costs of Children

Brother Correlations in Earnings in Denmark, 5 Finland, Norway and Sweden Compared to the United States 
A Comparison of the Human Capital and Signaling Models: The Case of the Self-Employed and the Barrachina

Selection Correction in Panel Data Models: An Application to Labour Supply and Wages The Recent Danish Experience

Wages and the Demand for Health - A Life Cycle Analysis

Reforming the Financial Incentives of the Welfare System Skilled Immigrants in the United States 
177 B. R. Chiswick

G. Repetto

178

R. Euwals

M. Ward

179 E. Wasmer

P. Weil

180 T. K. Bauer

I. N. Gang

181 E. Wasmer

Y. Zenou

182 M. Fertig

C. M. Schmidt

183 M. Fertig

C. M. Schmidt

184 M. Corak

B. Gustafsson

T. Österberg

185 H. Bonin

K. F. Zimmermann

186

C. Dustmann

187

T. K. Bauer

M. Lofstrom

K. F. Zimmermann
Immigrant Adjustment in Israel: Literacy and

Fluency in Hebrew and Earnings

The Renumeration of British Academics

The Macroeconomics of Labor and Credit Market Imperfections

Sibling Rivalry in Educational Attainment:

The German Case

Space, Search and Efficiency

Discretionary Measures of Active Labor Market

Policy: The German Employment Promotion Reform in Perspective

Aggregate-Level Migration Studies as a Tool for 1 Forecasting Future Migration Streams

Intergenerational Influences on the Receipt of

Unemployment Insurance in Canada and Sweden

The Post-Unification German Labor Market

Temporary Migration and Economic Assimilation

Immigration Policy, Assimilation of Immigrants and Natives' Sentiments towards Immigrants: Evidence from 12 OECD-Countries
3

4

$8 / 00$

1

$8 / 00$

$5 \quad 8 / 00$

$5 \quad 8 / 00$

$3 \quad 8 / 00$

$3 \quad 8 / 00$

$7 / 00$

$7 / 00$

$8 / 00$

$8 / 00$

$8 / 00$

$8 / 00$

$8 / 00$

$8 / 00$

$8 / 00$

1

\author{
(1)
}

188 A. Kapteyn

A. S. Kalwij

The Myth of Worksharing

A. Zaidi

189

W. Arulampalam

Is Unemployment Really Scarring? Effects of

Unemployment Experiences on Wages

An updated list of IZA Discussion Papers is available on the center's homepage www.iza.org. 